\title{
A gazdasági marginalizáció és a szélsôséges ideológiák iránti fogékonyság közötti kapcsolat
}

\author{
The Relationship Between Economic Marginalisation and \\ Susceptibility to Extremist Ideologies
}

Sipos Xénia Zsuzsanna

https://doi.org/10.47707/Kulugvi_Szemle.2021.3.7

Összefoglaló: A Soufan Group 2015-ös jelentésébỏl kiderült, hogy abban az évben mintegy 6000 - Líbiában pedig további 1500 - harcossal Tunéziából indultak el a legnagyobb számban dzsihadisták, hogy az Iszlám Állam oldalán harcoljanak, jóllehet ez az adat a lakosság számához viszonyítva elenyésző, csupán annak 0,1 százalékát teszi ki. Habár a 2017-es jelentés már „csupán” 2926 tunéziai fegyverest említett, a 2013 óta elkövetett terrorcselekmények - amelyek közül a hivatalos források szerint a legutóbbinak a 2020. szeptember 6-án, Port el-Kantávíban végrehajtott merénylet tekinthető - szüikségessé teszik az erőszakos radikalizáció jelenségéhez vezető okok átfogó vizsgálatát. A tanulmány a gazdasági kirekesztettség és az extrémista nézetek iránti fogékonyság közötti esetleges összefüggést vizsgálja. A kérdéskört a szerző kvantitatív adatok felhasználásával elemzi: az ország egyes régióinak a gazdasági és szociális mutatóit a legnagyobb számú dzsihadistát kibocsátó tartományokéval veti össze, valamint további következtetéseket von le a dzsihadisták profiljára vonatozóan. A tanulmány végén egyértelművé válik, hogy az erőszakos radikalizáció egy komplex folyamat, amelyhez a gazdasági okok mellett mind politikai, mind pedig kulturális tényezők nagymértékben hozzájárulnak.

Kulcsszavak: Tunézia, erőszakos radikalizáció, gazdasági kirekesztettség, terrorcselekmények

Abstract: The 2015 report of The Soufan Group identified Tunisia as the leading country in the ranking of recruitment 1o ISIS with approximately 6,OOO foreign fighters and an additional 1.500 jihadi fighters operating in Libya. though this number makes up only a small, O.1\% of the population. Although the 
2017 report mentions 2926 Tunisian fighters, the terrorist allacks commilted after 2013 - that according to the official sources recently rocked the town of Porl El Kanlaoui on 6 Seplember 2020 - require a comprehensive analysis of the root causes leading to violent radicalisation. The study examines the possible correlation between economic marginalisation and receptivity to extremist ideologies. The author examines the aforementioned topic by the application of quantitative data: the economic and social indicators of each region of the country are compared with those regions that emit the largest number of jihadists. Moreover, consequences are also drawn from the profile of jihadi fighters. The study finds that violent radicalisation is a complex phenomenon and that in addition to economic causes, political and cultural factors also contribute to this process.

Keywords: Tunisia, violent radicalisation, economic marginalisation, terror acls

\section{Bevezetés}

Vitathatatlan tény, hogy az Iszlám Állam (ISIS) és más extremista szervezetek (al-Káida, an-Nuszra, Boko Haram) által végrehajtott ter rorcselekmények, valamint az azok végrehajtása érdekében folytatott egyéb tevékenységeik (toborzás, agitáció), illetve az erőszakos akci ók elleni küzdelem korunk egyik legnagyobb kihívását jelenti a világ minden állama számára. Tekintettel arra, hogy az emlitelt szervezetek a vallást csak puszla eszközként használják a saját céljaik eléréséhez és az önigazolásuk érdekében, az önmeghatározásukból adódóan a toborzási tevékenységük többnyire, de nem kizárólagosan muszlim or szágokhoz köthető. Mindez nemcsak a különböző vallási csoportok békés együittélését, a vallások közötti párbeszédet nehezíti meg, de egyúttal a terrorizmus elleni küzdelem - mint a nemzetközi közösség egészét érintó, világméretü probléma és kihivás (vallástól függellen) komplex jellegét és azzal összefüiggésben az Iszlám Állam toborzása és tevékenysége következtében kialakuló vagy eszkalálódó társadalmi konfliktusokból fakadó nehézségeket is tükrözi.

Az Iszlám Állam toborzási tevékenységével összefüggésben érdemes megjegyezni, hogy a Soufan Group (TSG) szerint 2015 ben Tunéziából indultak útnak a legnagyobb számban dzsihadista 


\section{Külïgyi Szemle}

harcosok, hogy az Iszlám Állam oldalán harcoljanak, miközben a nemzetközi közösség az észak-afrikai országra az „arab tavasz” sikertörténeteként emlékezik, amely - a régió többi országával ellen tétben - elkerülte, hogy a bukott államok sorsára jusson. Csizmadia Sándort idézve, ,az "arab tavasz"végén Tunézia maradt az egyetlen or szág, ahol a szabadság értékeit megörizve folytatódott a demokratikus átmenet" (Csizmadia, 2014, 18. o.). A kormány és a lakosság erőfeszítéseinek eredményeként tehát a Freedom House éppen abban az évben kategorizálta első ízben Tunéziát szabad országként (Macdonald és Waggoner, 2018), amelyben a TSG az Iszlám Államnak a legtöbb külföldi harcost adó államként. A tanulmány célja ennek az ellentmondásnak az átfogó elemzése, magyarázata. Azt azonban már most ki kell emelni, hogy az erószakos radikalizáció vizsgálata során nem vonhatók le a társadalom egészére vonatkozó általánositások. A tuniszi központú statisztikai tanulmányokat készítő Sigma Tanács (Sigma Conseil) 2012. márciusi közvélemény-kutatása szerint a tunéziai lakosság 50,9 százaléka tartott a vallási szélsőségesek térnyerésétől, 48,8 százalék pedig sem a szekuláris, sem a vallási oldalhoz nem so rolta magát (Yahmed, 2012).

A jelen tanulmány Tunézia erőszakos radikalizációhoz vezető út ján keresztül kívánja beazonosítani, illetve elemezni az extrémista csoportok felemelkedését kiváltó alapvető okokat. Habár a szerző elsősorban gazdasági kontextusba ágyazva igyekszik megközelíteni az adott témakört, annak komplexilása szükségessé teszi az egyéb - elsósorban társadalmi és kulturális - folyamatok megvizsgálását is. Tunéziában az „arab tavaszt” követő események nagymértékben hozzájárultak az erőszakos cselekményekhez ugyan, illetve felgyorsították azok számának a növekedését, e probléma mögöttes és valódi okai jóval mélyebben gyökereznek, és az észak-afrikai ország sajátos történelmi, politikai és gazdasági fejlődési útjával magyarázhatók. A tanulmány révén a következő tézis igazolására teszek kísérletet: annak ellenére, hogy a gazdasági kirekesztés az erôszakos radikalizáció jelenségéhez vezető motívumok egyike, az inkább kiegészítő, mintsem az erőszakos cselekményeket közvetlenül kiváltó okként kezelendő. Az „arab tavasz” 
célkitűzései között szereplő politikai, társadalmi és gazdasági refor mok elmaradása olyan kihívást teremtett az ország számára, amely hozzájárult a tunéziai fiatalok erószakos radikalizációjához. A Zín el-Ábidín ben Ali (Ben Ali) elnök 2011. január 14-i bukását követő, fokozatosan romló biztonsági helyzet - amelyhez elengedhetetlen a regionális kontextus vizsgálata is - szintén az erôszakos radikalizáció folyamatát erősítette.

Ahhoz, hogy a tanulmány fókuszát képező gazdasági kirekesz tettség és az extrém ideológiák közötti összefüggést meg lehessen vizsgálni, elengedhetetlennek tűnik a radikalizálódott személyek általános profiljának a feltérképezése és az ország különböző régiói ra vonatkozó statisztikai adatok (munkanélküliségi ráta, írni-olvas ni tudók aránya) kielemzése is. Azonban nagyon fontos a politikai erőszak történelmi folyamatának, hátterének a vizsgálata is. Ignacio Sánchez-Cuenca a múvében említést tesz arról, hogy a radikalizmus és az extrémizmus gyakran együtt járó folyamat, a terrorizmus pedig a politikai és gazdasági rendszerből fakadó jelenség (Sáchez Cuenca, 2019, 20-23. o.).

Az erőszakos radikalizáció kérdéskörének vizsgálatát elsősorban a The Soufan Group által 2015 decemberében végzett felmérés eredményei indokolják, amelyek szerint a levantei régióban (as-Sám), illetve az észak-afrikai térségben Tunéziából vettek részt a legnagyobb számban dzsihadista harcosok az Iszlám Állam oldalán. A 2015. októberi adatok alapján mintegy 6000 tunéziai állampolgár - köztük 700, a Dzsihád al-Nikáhban' érintett nó, valamint 1500, Líbiában tartóz kodó dzsihadista - harcolt az Iszlám Állam (ISIS) oldalán (The Soufan

1 A Dzsihád al-Nikáhban (szexdzsihád) érintett nők a „szent háborút” vívó férfiak számára önként ajánlják fel a szolgálataikat (a nikáh szó valójában házasságot je lent). A kifejezés meglehetősen ellentmondásos: szexuális érintkezés és/vagy há zasság révén vívott küzdelem az Isten útján. A szexdzsihád fogalma a Mohamed al-Arífi által 2013-ban kiadott fatvához (vallásjogi döntés) kapcsolódik, amelyben a vahhábita teológus amellett érvelt, hogy a szükség megkövetelheti bizonyos ti lalmak (ld. paráznaság) áthágását, és arra biztatta a fiatal nőket, hogy a szolgála taikkal segítsék a szíriai fronton harcoló mudzsáhidokat (Dialmy, 2019). 


\section{Külïgyi Szemle}

Group, 2015, 9. o.).2 A pontos számukat illetően fontos megjegyezni, hogy az a későbbiekben csökkent, így a TSG 2017-es adatai szerint e téren Tunézia az első helyről a negyedikre esett vissza. Az ISIS-hez csatlakozott nők és gyerekek száma tekintetében ugyanakkor csupán Oroszország (3417 fö) elôzi meg Tunéziát, ahol e kategóriában 3000 fôt regisztráltak (Barrett, 2017, 9-13., 24-25. o.) Megjegyzendő ugyan akkor, hogy a több mint tízszer nagyobb lakosságú Oroszországhoz viszonyítva ez az adat - Tunéziával ellentétben - elenyészőnek mondható.

Szintén hangsúlyozandó, hogy a tunéziai társadalom körében - az iszlamistákat is beleértve - a dzsihadista szervezetek egyáltalán nem élveztek széles körủ támogatást (Lounnas, 2019, 110. o.), továbbá a 2015-2016-os terrorhullámot követően a tunéziai kormánynak - a már 2014-ben elkezdett erőfeszítéseinek köszönhetően - a terrorista szervezeteket nagyrészt sikerült visszaszorítania. A társadalom részéről tapasztalt elutasításuk, valamint a megfékezésük érdekében tett intézkedések következtében a tunéziai szélsőségesek a terrorakcióikat elsôsorban az ország határán kívïl hajtják végre - például Nizzában, ahol ők voltak az elkövetői a 2020. október végi késeléses és a 2016 os gázolásos merényletnek is (Reuters, 2020). A közel-keleti régióban a Dáis ${ }^{3}$ által 2017 vége óta fokozatosan elszenvedett szíriai és iraki területi veszteség (Winston, 2018, 4-5. o.) 2019 tavaszára a szervezet jelentős részének a felszámolásához vezetett, ugyanakkor az általa jelentett fenyegetés lehetősége sem Tunéziában, sem Európában nem szűnt meg. A Tunézián 2015-2016-ban végigsöprő terrorhullám mellett a legutóbbi, 2020. szeptember 6-án Port el-Kantáví kikötôvárosban, illetve azt megelőzően, 2020 márciusában (Euronews, 2020),

2 A külföldi harcosok ország szerinti bontásban megjelenítő rangsorát a 3. ábra tartalmazza.

3 A Dáis az Iraki és Levantei Iszlám Állam, illetve röviden csak Iszlám Állam (ISIS) arab nevének (ad-Daula al-Iszlámijja fil-Irák $v a-S$-Sám) a rövidítése, amely arra a Dél-Törökországtól Szíriáig terjedő területre utal, ahol a szervezet létrehozta a saját államát. 2014-től ezt az elnevezését használja Franciaország is, hogy elkerülje az iszlám, iszlamizmus és muszlim kifejezések közötti határok összemosását (Black, 2014). 
2019 júniusában (LExpress.fr, 2019) és 2018 októberében (Le Figaro.fr, 2018) Tuniszban elkövetett merényletek egyaránt azt bizonyítják, hogy az erôszakos radikalizáció jelenségének a Tunézia példáján keresztül történő átfogó elemzése kiemelt fontossággal bír.

A tunéziai kormánynak a szélsőséges iszlamisták megfékezése érdekében tett lépéseire visszautalva fontos hangsúlyozni, hogy a szalafistáknak a 2011. októberi választásokat követő térnyerése kapcsán az ország vezetése felismerte, hogy a szélsőségesek által támasztott követelések nem tükrözik a tunéziai társadalom realitását Az erőszakos radikalizációval szembeni intézkedések mutatkoznak meg a 2014 januárjában elfogadott alkotmányban is, amelyből végül kimaradt a sariára történô utalás (Csizmadia, 2014, 24. o.).

A tunéziai radikalizáció folyamatának a megértéséhez a szerző kiindulópontként adatokra és tényekre támaszkodva, valamint a ter rorcselekmények különbözö kategóriáinak a bemutatásával igazolja, hogy Tunéziában az „arab tavaszt” követő biztonsági helyzet fokozatos romlása magával hozta az extrémista csoportok felemelkedését, amely jelenség a 2015-2016-os terrorhullámban nyilvánult meg.

\section{A tunéziai biztonsági és belpolitikai helyzet 2011 után: a föbb terroreselekmények kategorizálása}

Az „arab tavasz” eseményeit követő instabil politikai és biztonsági helyzet - a politikai vákuum, az annak következtében zajló hittéríté si tevékenység (da'wa) (Law, 2015, 344. o.), az akár a terrorszerveze tekhez köthető politikai foglyoknak, mint az Anszár as-Saría (AST) alapítójának, Abú Ijádnak (Zaarour In: Dawoody, 2016, 190.o.) adott amnesztia - megnyitotta a lehetóséget az ún. reradikalizációs folyamat számára.

Az Anszár as-Saría az ideológiáját tekintve az al-Káida terrorszer vezethez kapcsolódik, s 2011 áprilisában Tunisz Szukra negyedében alakult meg, kihasználva az „arab tavaszt” követő politikai vákuumot. Besenyő János és Prantner Zoltán szerint a szervezet a megalakulásakor egyfajta humanitárius szerepet kívánt betölteni a belpolitikai 


\section{Külïgyi Szemle}

válságban, néhány hónappal később azonban az egyre kritikusabbá vált gazdasági és társadalmi helyzetből, a politikai kontroll lazulásából előnyt kovácsolva már az iszlám vallási normákat egyre erőszakosabb eszközökkel kívánta a társadalomra ráerőltetni (Besenyő és Prantner, 2015, 137-139. o.). Az államszerkezet fennmaradása következtében Tunézia nem bizonyult alkalmasnak az országon belüli dzsihád viszszaszorítására, a terrorizmus veszélyét azonban tovább növelte, hogy 2014 januárjában az AST és katonai szárnya, az Okba Ibn Náfi Brigád egyesült, és az így létrejött, az al-Káida tunéziai szárnyaként is emlegetett szervezet a tunéziai-algériai határ porózusságát kihasználva a mai napig a régió aktív szereplóje (Kiss, 2015, 123. o.).

Az extrém ideológiák fokozódó térnyerése a 2013-ban elkezdődött terrorhullám mellett abban is megmutatkozott, hogy egyre több tunéziai dzsihadista hagyta el az országot, hogy az Iszlám Állam oldalán Szíriában, Irakban vagy Líbiában harcoljon. Míg a korábbi elnökök, Habíb Búrgíba és Ben Ali idején a modernizációs törekvések eredményeként a vallási szféra háttérbe szorult, 2011 októbere után egyre inkább előtérbe került: a biztonsági apparátus közel 400 meeset felett vesztette el az irányítást (Wolf, 2014). Az instabil belpolitikai helyzet lehetóséget teremtett az ,arab tavaszt” követően szabadon bocsátott AST-tagok számára, hogy titokban folytassák a tevékenységüket. Bár az Anszár as-Saría mérsékeltebb ága a békésebb eszközök alkalmazását támogatta, és az iszlám vallás által dominált állam megteremtése céljából a mecsetekben folytatott hittérítő tevékenységet, a szervezet extrémista nézeteket valló képviselói 2012-től a Dáishoz való csatlakozásra buzdították a fiatal lakosságot, sőt sokan erőszakos eszközökkel, fegyverrel igyekeztek elérni a céljukat. Részt vettek - többek között - két ellenzéki politikus, Sokrí Belaíd és Mohamed Bráhmí 2013-as meggyilkolásában is (Fahmi és Meddeb, 2015, 8. o.).

4 A két szekuláris baloldali (Népi Front) politikus ellen 2013. február 6-án, illetve július 25-én elkövetett merényletért az akkori politikai vezetés a szélsőséges szalafita csoportokat tette felelóssé: Monszef Marzúki elnök (2011-2014) szerint a politikai pártok közötti viszály szításával kívánták aláásni az ország által elért sikeres átmenetet (Le Monde.fr; 2013). 
A radikalizálódott tunéziaiak számára vonatkozóan - a téma jel legénél fogva - konkrét adatok nem állnak rendelkezésre, ${ }^{5}$ csupán a közel-keleti régióban és Líbiában jelen lévő dzsihadisták korábban már említett, hozzávetóleges száma ismert. A terrorizmus jelensé gével foglalkozó tunéziai kutatóközpont 2016-os jelentése szerint a dzsihadisták 99,1 százaléka a 18 és 64 év közötti korosztályba tartozik (Mejri, 2017). Mivel ez a korcsoport a 11,8 millió fỏs lakosság (Central Intelligence Agency. The World Factbook, 2021) körülbelül 55,75 százalékát alkotja (megközelítőleg 6,5 millió fö), a külföldön elkövetett erőszakos cselekményekben csupán a lakosság elenyésző, 0,1\%-a vett részt; a terrorakciók súlyához képest ez az arány csekélynek mondható.

A tunéziai erőszakos radikalizáció jelenségének a megértése szempontjából fontos kiemelni, hogy az országban elkövetett terror cselekmények három nagy kategóriába sorolhatók:

- a tunéziai GDP 7,4 százalékát adó és a lakosság 14 százalékát foglalkoztató turisztikai szektort (Alby, 2015) célzó erőszakos cselekmények;

- a kirekesztô rezsimmel szemben elkövetett, politikai indíttatá sú terrorakciók;

- a terrorszervezetek (pl. az ország nyugati, Algériával határos területein, az as-Saánbí-hegyen aktív Okba Ibn Náfi Brigád) tevékenységei (TRAC, é. n.).

A legnagyobb tunéziai szigeten, Dzserbán fekvő el-Gríba zsinagógába látogató turistacsoport ellen 2002. áprilisban elkövetett támadást (Aubin, 2011, 23. o.) követően, 2013 februárjában újabb ter roreselekmények sújtották az országot, amelyek mindegyike politikai indíttatású volt. A Sokrí Belaíd, majd Mohamed Bráhmí ellen elkövetett merényletekért (Moghadam, 2016) - amint arról már szó volt -

5 Az Inkyfada honlapján megjelent 2017-es tanulmány (Mejri, 2017) szerzője meglehetősen részletes áttekintést nyújt a tunéziai dzsihadisták profiljáról (régiók szerinti megoszlás, életkor, iskolai végzettség stb.), s a régiókra vonatkozó társadalmi-szociális mutatókkal összevetett eredményeket „A szegénység és az extrém ideológiák közötti pozitív összefüiggés, avagy tényleg a szegénység tehető felelőssé a terrorcselekmények elkövetéséért?” c. alfejezetben ismerteti. 


\section{Külïgyi Szemle}

az Anszár as-Saría vállalt felelősséget. Az erőszakos cselekmények csúcspontját azonban 2015 jelentette: abban az évben elsősorban tu risták kerültek a szélsőséges iszlamisták célkeresztjébe. Október 18 án két fegyveres hatolt be a tuniszi Bárdó Múzeumba; a támadásnak összesen 21 turista és egy helyi rendőr esett áldozatul (Bobin, 2016). Június 26-án az ország északkeleti részén fekvő városból, Szilijánából származó Szajf ad-Dín ar-Rezgí 38 turistát mészárolt le a Szúszához közeli kikötő, Port el-Kantávíban álló Riu Imperial Marhaba Hotel tengerpartján (France 24 in Arabic, 2015). A terroristák akciói követ keztében a turisztikai szektorban 2014 és 2016 között 2,5-3 száza lékos volt a visszaesés (Duthion és Mandou, 2016). Kiderült, hogy a terrorcselekmények a turisztikai szektorban a politikai instabilitásnál, valamint a globális sokkoknál (pl. 2001. szeptember 11. vagy a 2008-as pénzügyi világválság) jóval nagyobb mértékủ és hosszabban elnyúló krízist okoznak (Goaied, 2019, 11. o.).

A politikai indíttatású terrorcselekmények 2015 végén kezdődtek meg. November 24-én a Dáis az elnöki ôrség tagjait szállító busz ellen követett el robbantásos merényletet, amelyben 13 fơ vesztette életét (Business News.com.In, 2015). 2016. március 7-én Ben Gardán városá ban fegyveres csoportok katonai tisztviselőket és barakkokat támadtak meg, s az akció során 36 terrorista, 7 civil és a biztonsági erők 12 tagja vesztette életét (Human Rights Watch, 2017, 597. o.). Hangsúlyozandó, hogy az e kategóriába sorolható terrorakciók a tunéziai társadalomnak kizárólag az extrém ideológiák iránt fogékonyságot mutató tagjaihoz köthetők. Az elkövetők célja a 2011-ben megkezdett demokratikus át menet folyamatának a megbomlasztása. Szintén a politikai hátterú tá madások sorába illeszkedik a 2018. október 29-én Tunisz belvárosában elkövetett öngyilkos merénylet (egy 30 éves nő robbantotta fel magát), amelyben 20 személy sérült meg. 2019. június 27-én ismét terrorista akció rázta meg Tuniszt: az erőszakos cselekménynek egy rendőr esett áldozatul. 2020. március 6-án az Amerikai Egyesült Államok tuniszi nagykövetsége közelében található rendőri ellenőrző pontnál végrehajtott merényletben a biztonsági erők öt tagja vesztette életét. A szeptember 6-án Port el-Kantávíban történt késelést - amely egy rendôr halálát okozta - az Iszlám Állam vállalta magára. 


\section{Az (eröszakos) radikalizáció jelenségének fogalmi kerete}

Fogalmi elhatárolás:

radikalizmus (radikalizáció), extrémizmus és terrorizmus

Mindenekelőtt ki kell jelenteni, hogy az erószakos radikalizáció fogalma nem határozható meg egy konkrét definíció segítségével, mivel annak folyamatára politikai, társadalmi, gazdasági és pszichológiai tényezők egyaránt hatással vannak. A témakör komplexitása mind a közvetlen kiváltó okok, mind a befolyásoló push and pull tényezők áttekintését szükségessé teszi. Míg az elsőket illetően a szakértők között konszenzus mutatkozik, az utóbbiak megjelenése és csopor tosítása kapcsán már a véleményüik megoszlik (Dzhekova, Mancheva, Anagnostou és Stoynova, 2016).

A közismert, ám nem teljesen pontos nyugati terminológiában a radikalizmus gyakran az extrémizmus szinonimája. Ez az értelmezés azonban nemesak pontatlan, de esetenként kontraproduktiv is lehet. A szó eredeti, latin nyelvú jelentése szerint ${ }^{6}$ a radikalizmus - az extrémizmustól eltérően - a korábbi normák és gyakorlatok alapvető, de jogszerü keretek közöı zajló változását eredményező folyamatként írható le, igy nem kezelendő automatikusan a Nyugat ellen irányuló dzsihadista tevékenységek támogatásaként, sôt bizonyos mértékig nyitottságot is mutat a nyugati kultúra egyes elemei iránt. A radikalizmus fő célja a gyökeres változások elérése, amelyek azonban nem sértenek törvényes kereteket. A radikalizmus célja tehát a meglévó politikai rendszerben és normákban történó jelentös változlatások el érése - de a fogalom nem kizárólag negatív kontextusban használandó (a pozitív értelmű alkalmazását ld. a kulturális tényezőkről szóló részben). Ignacio Sánchez-Cuenca szintén e megállapítást erősítette meg, amikor azt hangsúlyozta, hogy a radikalizmussal ellentétben az

6 A latin radix fơnév eredeti jelentése: gyökér; ebből jött létre késóbb a radicalis [alapvető] melléknév, amely elsődlegesen nem negatív kontextusban használatos, és nem is feltétlenül negativ történésre utal. 


\section{Külïgyi Szemle}

extrémizmus magában foglalja az erőszak alkalmazását. Ugyanakkor hozzátette, hogy a két fogalom gyakran egymással szorosan összefügg, hiszen a politikai, gazdasági és társadalmi rendszerben változásokat kívánó egyének és csoportok egy idő után a céljaik megvalósítása érdekében erőszakos eszközökhöz nyúlnak. Történelmi perspektívában: a polgárháború vagy demokratikus válság sújtotta, túl későn iparosodott országok évtizedekkel később a baloldali terrorizmus áldozatává váltak (Sáchez-Cuenca, 2019, 20-23. o.). A fogalom pozitív és negatív tartalmának elhatárolása érdekében a tanulmány az utóbbi esetben a radikalizáció szó előtt az erószakos jelzőt alkalmazza.

Patrick H. Tolan szerint az erőszak definiálása kapcsán elengedhetetlen, hogy a tettek mögött álló különböző motivációkat, hatásokat, társadalmi, politikai és pszichológiai tényezőket is figyelembe vegyük, amelyek mind eltérô perspektívába helyezik a fogalmat. Szintén hangsúlyozandó, hogy az elkövetett cselekmények következménye a másik fél bántalmazása - ám a szakértők véleménye megoszlik arról, hogy csak a fizikai, vagy a verbális cselekedetek is erőszakosnak minősüilnek-e (Tolan, 2007). Brynjar Lia azt emeli ki, hogy az extrém ideológiák iránti fogékonyság társadalmi és szociális tényezőkkel hozható összefüggésbe, de az e nézetekkel való egyetértés önmagában nem vezet terrorista cselekmények elkövetéséhez. Ez utóbbi hátterének a megértéséhez szüikséges a pszichológiai sík vizsgálata is (Lia, 2005, 159. о.).

Mivel az extrémizmus célja a társadalom érdekeit szolgáló jogi normák áthágása, az erőszakos cselekmények iránti fogékonyság leírására ez a szó bizonyul a legalkalmasabbnak. A radikalizmussal ellentétben a terrorszervezetek, illetve a terroristák erőszakos cselekmények elkövetésével „legitimálják” magukat. Az amerikai külïigyminisztérium (U.S State Department) 1983-ban elfogadott definíciója szerint a ter rorizmus: előre eltervezett, politikai indíttatású, az állam alatti sze replők vagy tiltott csoportok által a társadalom valamely rétegének a befolyásolása érdekében nem kombattáns célpontok elleni erőszakos cselekmény(ek) (Krueger és Maleckova, 2002, 3. o). A radikalizmus - pozitív és negatív kontextusban való értelmezhetősége ellenére - 
gyakran a terrorcselekmények egyfajta előzményének tekinthető, és ahogy arról korábban is szó volt, mindkettő komplex folyamat, így az alapvető okaik is szorosan összekapcsolódnak (Taspinar, 2009, 76. o). Egyes kutatók szerint az erószakos radikalizáció folyamata egyrészt küilső tényezőkkel (politikai, gazdasági és társadalmi), másrészt belső okokkal magyarázható. Mindemellett az Iszlám Állam által biztosított jólét és a közösséghez tartozás érzése (ld. csoportszolidaritás) szintén a fiatal dzsihadisták első számú motivációi közé tartozik (Arany, N. Rózsa és Szalai, 2016, 195-198. o).

\section{Fókuszban a gazdasági kirekeszlettség és az extrémizmus}

Martha Crenshaw, aki már az 1980-as évek elején foglalkozott a terrorizmus kérdéskörével, úgy vélte, hogy a szegénység azzal nem áll összefüggésben, mert a radikalizáció három összetevője a csoportszolidaritás, a mártíromság, valamint az elit részéről az aktuális politikai rendszerrel, illetve a korrupcióval való szembehelyezkedésének a kifejezése. Crenshaw mindemellett kiemelte, hogy a terrorcselek mények elkövetői fiatal, iskolázott, a középréteghez tartozó szemé lyek (Crenshaw, 1981, 383-384., 389. és 394-395. o.). Tekintettel arra, hogy az erószakos radikalizáció jelenségét vizsgáló szakértők véleménye is megoszlik arról, hogy valóban főleg a szegénység-e a felelős a terroristák akcióiért, számos egyéb tényezôt is figyelembe kell venni.

Avraham Jager empirikus bizonyítékok alapján elutasította az emlitett két variáns közötti pozitív korrelációt, és megállapította, hogy az erőszakos radikalizáció nem szûkíthetô le bizonyos földraj zi régiókra vagy kultúrákra (Jager, 2018, 8-9., 12. o.). A racionális választás elmélete - amely az egyént tekinti a kiindulópontnak, és az emberi viselkedésre keresi a választ - szintén cáfolja a szegénység és az extrém ideológiák iránti fogékonyság közötti összefüggést. Az elmélet szerint az egyén a legelőnyösebb és a legnagyobb haszonnal járó lehetőséget veszi figyelembe, így a döntések mérlegelésekor a számára legideálisabb opciót választja (Ogu, 2013, 90., 92-93. o.). Gary S. Becker - aki elsőként alkalmazta a racionális választás elméletét a 


\section{Külïgyi Szemle}

közgazdaság-tudományon kívül más tudományterületekre - szintén az előző megállapításokat erősítette meg: a bűncselekmények elkövetésekor számtalan tényező (befektetett pénz, esetleges kockázatok) befolyásolja az egyéni döntéseket (Jager, 2018, 10. o.). Quan Li és Drew Schaub a gazdasági fejlettség és a gazdasági globalizáció kérdéskörét vizsgálva arra a megállapításra jutott, hogy egy ország gazdasági fejlettsége jelentős mértékben csökkenti az erőszakos cselekmények előfordulásának a mértékét, ezért ők a politikai vezetés részéről a gazdaság fejlesztésére irányuló erőfeszítések szüikségességét hangsúlyozták (Li és Schaub, 2004, 254. o.).

Az eddigiek alapján tehát elmondható, hogy a nehezebb körülmé nyek között élők mindennapjait jobban leköti az alapvető szükségle teik kielégítése, míg a középosztálybeli, magasabb iskolai végzettségủ személyek a változások érdekében nagyobb valószínűséggel kapcsolódnak be a politikai életbe. A témával foglalkozó szakértők írásaiból összességében az derül ki, hogy az erószakos radikalizáció jelensége mögött elsősorban az érintett személynek az adott politikai rendszerrel való elégedetlensége, valamint az egyéb sérelmei következtében felgyưlt haragja áll. Mindemellett az államoknak a gazdaságfejlesztés érdekében tett intézkedései - mint a terrorcselekmények visszaszorításának a potenciális eszközei - sem hagyhatók figyelmen kívïil.

A következő fejezet a szegénység és az erőszakos radikalizmus ide ológiája iránti fogékonyság vizsgálatával foglalkozik, a politika és a kul túra szintjén megjelenő egyéb járulékos tényezőket is érintve.

\section{A tunéziai társadalom erószakos radikalizálódásának alapvetố okai}

A szegénység és az extrém ideológiák közötti összefüggés, avagy tényleg a szegénység tehetốfelelóssé a terrorcselekmények elkövetéséért?

Khodr M. Zaarour szerint a modern államok felelősséggel tartoznak az állampolgáraik társadalmi jólétének biztosításáért. Amennyiben egy állam nem képes teljesíteni azon alapvető feladatait, amelyek 
ellátására a néptől felhatalmazást kapott, az a kormánnyal szembe ni általános elégedetlenség növekedését eredményezi, amely könnyen terrorcselekmények elkövetéséhez vezet (Zaarour, 2016, 190. o.).

A gazdasági színtér vizsgálata során elsősorban a fiatal diplomások körében tapasztalható magas munkanélküliségi rátát szükséges kiemelni, amely Tunéziában országos szinten 40 százalék körülire tehető (World Bank, 2014). A tunéziai munkaerőpiaci egyenlőtlenségek a fiatal diplomások körében egyre növekvő elégedetlenséget váltottak ki. Közvetlenül az „arab tavasz” után végzett felmérés szerint a lakosok 44 százaléka vélte úgy, hogy 2011 óta sem történt pozitiv irányú változás, és 46 százalék szerint az országban uralkodó helyzet a Ben Ali-éra alatt tapasztaltnál is rosszabb (Colombo, 2016). Valentina Colombo a politikai, társadalmi és kulturális kirekesztést hangsúlyozta, illetve a nagyobb városok és a peremterületek közötti hatalmas társadalmi és gazdasági különbségeket emelte ki. Az utóbbin - köztük a főváros elmaradott kerületein (Ben Arúsz, Arijána) - élő személyek a munkaerőpiacon eleve jelentős hátránnyal indulnak. Az egész Magreb régión belüli 15-29 éves korosztály körében Tunéziában éri el a legmagasabb értéket (33\%) a NEET mutató ${ }^{7}$ (Colombo, 2016).

A jelen tanulmány a gazdasági marginalizáció és az extrémista nézetek közötti - esetleges - összefüiggés vizsgálatakor alapvetően a The Soufan Group 2015-ös, valamint a terrorizmus jelenségével foglalkozó tunéziai kutatóközpont 2016-os anyagára (Mejri, 2017) épít. Ez utóbbi Tunézia mind a 24 tartományának a figyelembevételével mutatja meg, hogy melyik régió milyen arányban bocsátott ki dzsihadista harcost. Ezek az adatok, továbbá az erőszakos radikalizáció által befolyásolt fiatalokról vázolt profilt az egyes régiók munkanélküliség, illetve az analfabetizmus arányával hasonlítom össze. A lehető legnagyobb hitelesség érdekében a felhasznált mutatók a tunéziai Nemzeti Statisztikai Hivatal (Institut National de la Statistique, INS) publikációiból származnak. Mivel az INS a munka-

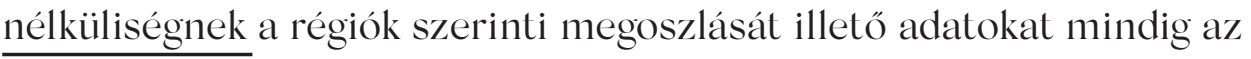

7 A NEET (Not in Education, Employment or Training) az oktatásban, a munkaerőpiacon vagy a képzések közül egyikben sem részt vevő személyek összlétszámára utaló mutató. 


\section{Külïgyi Szemle}

év második trimeszterében teszi közzé, a jelen tanulmányban találha tó fontosabb statisztikai mutatók is annak megfelelően szerepelnek. ${ }^{8}$ Kiemelendő még, hogy a Tunézia összes kormányzóságát lefedő ada tok kizárólag 2015 második trimeszterétől érhetők el, így azok szintén beleillenek a vizsgált időszakba.

A TSG 2015-ös felmérése szerint a tunéziai dzsihadisták egyharmada az alábbi három régióból származik (ld. 4. ábra): Ben Gardán (15,2\%), Binzert kormányzóság (10,7\%) és a főváros, Tunisz (10,7\%) (The Soufan Group, 2015, 5., 11. és 16. o.). Közülük az elsô város neve - a Líbiához való közelsége miatt - mindig is szorosan összefonódott a csempészettel, a másik két régió pedig az ország északi részén fekszik. Az északi-déli és a nyugati-keleti régiók közötti társadalmi-gazdasági törésvonal megértéséhez fontos tudni, hogy a Búrgíba, majd a Ben Ali által végrehajtott modernizáció csak az északi és a part menti területekre terjedt ki, míg a déli és a nyugati régiók elszegényedésével járt. Az állami befektetések mintegy 65 százaléka a part menti tér ségbe (Tunisz, Szúsza, Monasztír) irányult, s a vállalatok csupán 3 százaléka települt az ország nyugati részébe (Daguzan, 2017, 4. o.). E tények alapján magától értetődő lenne kijelenteni, hogy a gazdasági szempontból marginalizált déli és nyugati területek alkotják a legnagyobb számú tunéziai dzsihadistát kibocsátó régiót.

A tanulmány fő kérdésének elemzése szüikségessé teszi a főbb mu tatószámok - a munkanélküliség és az írni-olvasni tudók aránya - vizs gálatát. Az ENSZ statisztikái szerint Tunéziában a munkanélküiliségi ráta 2010-ben 13, míg 2014-ben átlagosan 15,3 százalékos volt. Az INS adataiból pedig az derül ki, hogy a munkanélküliek aránya 2015-ben még 15,2,9 2020 harmadik trimeszterében pedig már 16,2 százalék volt (UNdata, 2021). ${ }^{10}$ 2015-ben Ben Gardánban ugyanez a mutató

8 A munkanélküliség földrajzi megoszlását és az írástudatlanság által leginkább érintett régiókat az 1. ábra mutatja.

9 Ez az arány a diplomás fiatalok körében magasabb volt: átlagban a 23 százalékot is elérte. Bizonyos régiókban (pl. Szídí Búzíd vagy Dzsendúba kormányzóság) a mun kanélküliségi ráta 24,5 százalékra is megemelkedett (Statistiques Tunisie, 2021).

10 Fontos megjegyezni, hogy a 2020-as évre vonatkozóan kizárólag az országos szintű munkanélküliségi rátát közölte a tunéziai Nemzeti Statisztikai Hivatal, a régiók szerinti megoszlásra vonatkozóan konkrét adat nem érhető el. 
18,58, Binzert kormányzóságban 13,11, Tunisz marginalizált negyedeiben pedig 13,12 százalékos volt (Statistiques Tunisie, 2021). Az adatok alapján tehát a munkanélküliség által a legnagyobb mértékben sújtott régiók már 2012-től, de 2015 óta még egyértelmúbben az ország középső (pl. Gafsza kormányzóság, ahol a munkanélküliek aránya 2015 ben 27,9, 2016-ban 28,2, 2017-ben 27,3, 2018-ban 28,9, 2019 második trimeszterében pedig 25,5 százalék volt) és déli részén találhatók (pl. Tatávín kormányzóság a maga 2015-ös 30, 2016-os 32, 2017-es és 2018-as 32,4 és 2019 második trimeszterében mért 28,7 százalékos munkanélküliségi rátájával) (Statistiques Tunisie, 2021).

A terrorizmus jelenségével foglalkozó tunéziai kutatóközpont már többször is idézett 2016-os tanulmány írója a 2011 és 2015 közötti időszakra vonatkozóan összesen 384 bírósági aktát vizsgált meg, amelyben 2224, terrorcselekmény elkövetésével vádolt személyről tartalmazott információkat. Ez alapján arra a megállapításra jutott, hogy az elkövetők 96 százaléka férfi, 28,7 százaléka 25 és 29 év kö zötti, 40 százaléka egyetemen tanul vagy felsőfokú végzettséggel rendelkezik.

Az extrém ideológiára fogékony személyek regionális megoszlását illetően a tanulmány az első helyen Tuniszt, illetve annak külvárosi kerüileteit (Ben Arúsz, Arijána és Manúba) nevezi meg, ahonnan az elkövetők 32 százaléka származik, a második helyre pedig 14 százalékkal az ország középsô részén elhelyezkedő Szídí Búzíd tartomány került. Ezeket követi az ország nyugati részén található Dzsendúba (5,5\%), al-Kaszrín (5,39\%), a délkeleti Medenín (5,29\%), illetve Binzert kormányzóság $(5,19 \%)$.

Megjegyzendő, hogy a munkanélküiliségi ráta kapcsán leginkább érintett régiókból (Gafsza vagy Tatávín kormányzóság) a tanulmány szerint országos szinten kifejezetten alacsony arányú - 2,39, illetve 1,87 százaléknyi - dzsihadista származott. Az általános feltételezé sekkel ellentétben kiderült, hogy a vizsgálatba bevont, terrorista cselekmények elkövetésével vádolt személyek 33 százaléka középiskolai végzettséggel rendelkezett, 28 százalék egyetemi tanulmányokat folytatott, 12 százalékuk pedig egyetemi diplomával is bírt. A vádlottak 


\section{Külïgyi Szemle}

13 százaléka szakirányú képzésben részesült, 4 százalékuk érettségi zett, és alig 10 százaléknak van csupán általános iskolai végzettsége.

A foglalkozásuk alapján az extrémista ideológiák iránt fogékony nak mutatkozó személyek 45,5 százaléka szakképzett vagy szakkép zettség nélküili munkás; csupán 14,9 százalékuknak van világi, vagyis nem vallási tevékenységhez kapcsolódó szakmája; 8,3 százalékot tesznek ki a diákok, 6,6-et a szakképzett vagy szakképzettség nélküli köztisztviselők, 3,2 százalékot pedig az egyetemi tanárok. E számok szintén ellentétben állnak azzal az általános feltételezéssel, miszerint az alulképzettek, a gazdaságilag kirekesztettek körében - a kilátástalan helyzetból fakadóan - nagyobb a valószínúsége az erőszakos cselekmények elkövetésének.

A vádlottak életkorát illetően fontos kiemelni, hogy bár - ahogy arról már szó volt - a legtöbb elkövető a 25-29 évesek közüil kerül ki (28,7\%), óket arányukban a 30 és 34 év közötti korcsoport követi (25\%), de 18-24 éves fiatalok is szép számmal (22\%) találhatók a terrorizmus vádjával gyanúsított személyek között.

A kiképzés helyszíne kapesán meg kell említeni, hogy a tunéziai kormány 2013-as intézkedéseit (többek között az Anszár as-Saría terrorszervezetté nyilvánítását) követően a tunéziai dzsihadisták kiszorultak az ország területéről, és 70 százalékuk Líbiában, 23 százalékuk pedig Szíriában található dzsihadista táborokban részesült kiképzésben (Mejri, 2017).

A munkanélküliség és az írástudatlanság földrajzi megoszlását szemléltető térkép (1. ábra), a statisztikai adatok és a legtöbb dzsihadistát kibocsátó régiók összehasonlítása alapján tehát nem lehet egyértelmű összefüiggést találni a szegénység és az extrém ide ológiák iránti fogékonyság között, tehát az erôszakos radikalizáció je lenségét más tényezőkkel együtt szüikséges vizsgálni. 
A vizsgálandó témakör szempontjából lényeges kiemelni, hogy a szekuláris-vallási törésvonal mentén zajló politikai küzdelem már Tunézia Franciaországtól való 1956-os függetlensége óta jelentős mértékben meghatározza az ország politikai és kulturális karakterét. A Búrgíba elnök nevével fémjelzett modernizációs folyamat - vagyis a nyugati típusú modell átvétele - radikálisnak tekinthető ugyan, hiszen szakítást jelentett az iszlám vallásban mélyen gyökerező hagyományokkal, ám az ország modernizációját szolgálta, így a „radikális” jelző ez esetben pozitív kontextusban értelmezendő. A gyors ütemú fejlődés érdekében Búrgíba többek között eltörölte a vallási intézményeket (pl. saríabíróságok), valamint a nőket érintő intézkedései részeként 1957 ben betiltotta a hidzsábnak, az arcot szabadon hagyó fejkendőnek a tantermekben való viselését (Boer, Moors és Teeffelen, 1995, 59. o.).

A tunéziai államépítés folyamata a függetlenség kikiáltása után vette kezdetét, és egyet jelentett a politikai és a kulturális szintnek a központi hatalom kezében történő összpontosulásával. Búrgíba elnök említett reformjai egy sajátos helyi identitás megteremtését, az ún. Iunéziai iszlám létrehozását eredményezték. Az új ideológia szerint a tunéziai identitás már jóval az iszlám észak-afrikai térhódítása előtt létezett, így az utóbbi valójában egy berber társadalomra épült rá (Boer, Moors és Teeffelen, 1995, 60. o.). 1987-es hatalomra kerülését követően Ben Ali tovább erősítette a Búrgíba által megkezdett reformokat, köztüik az ország vallási karakterének a visszaszorítására tett intézkedéseket. A tunéziai identitásformálás egy sajátos, a többi arab országétól eltérő fejlődési folyamatként értelmezhető, ahol az identitás gyökerei elsődlegesen nem a vallásban keresendők. Ennek ellenére nem szabad elfelejteni, hogy a tunéziai nemzet alapvetően sokszínú és plurális, amely a szekuláris (elsősorban a part menti régiókban élô) és a vallási hagyományokhoz, tradíciókhoz a mai napig ragaszkodó (déli peremterületi) lakosságot egyaránt magában foglalja (Ben Yahmed, 2012). 


\section{Külïgyi Szemle}

A tunéziai államépítés kettős karaktere - egyfelől Tunézia polgári államként történő definiálása, amelyben az iszlám mint államvallás jelenik meg, másfelől pedig a felüilről jövő modernizáció és a vallás gyakorlás háttérbe szorítása - egyfajta diszharmóniát eredményezhet. Ennek következtében a helyi lakosság bizonyos rétege nehezebben tudja definiálni az állampolgárság fogalmát, illetve az iszlám vallásnak a mindennapokban betöltött szerepét. Ez a bizonytalanságérzet pedig könnyen hozzájárulhat ahhoz, hogy az egyén a szekularizmus helyett a hagyományos normákhoz térjen vissza, amely adott esetben az iszlám vallás félreinterpretálásában mutatkozhat meg. Minderre tekintettel kijelenthető, hogy a diszharmónia érzése szintén az eró szakos radikalizáció folyamatában szerepet játszó potenciális faktorként említhető, de a gazdasági kirekesztettséghez hasonlóan ez sem kizárólagos tényezô.

\section{Konklúzió}

A tanulmány átfogó fogalmi keretbe ágyazva kívánta elemezni az erőszakos radikalizáció komplex jelenségének az - egymást átfedő okait. E folyamat a csúcspontját jelentő 2015 során mintegy 6000 tunéziai állampolgárt érintett, jóllehet fontos hangsúlyozni, hogy az ország lakosságához viszonyítva az Iszlám Állam oldalán harcoló fiatalok aránya még mindig csekélynek mondható, csupán 0,1 százalékot tett ki. A fogalmi különbségtétel rávilágított a radikalizáció, valamint annak az erőszakos formája közötti küiönbség figyelmen kívül hagyásának a problematikájára. A tanulmány fókuszában a szegénység és az extrém ideológiák iránti fogékonyság közötti esetleges korreláció vizsgálata állt. Egyrészt a munkanélküiliség és az írástudatlanság, másrészt a dzsihadistákat a legnagyobb számban kibocsátó földrajzi régiók adatainak az összevetése igazolta az eredeti állítást: a gazdasági marginalizáció az erószakos radikalizáció folyamatának a járulékos, nem pedig a kizárólagos tényezóje. 
A tunézai esettanulmány továbbá Krueger és Maleckova (2002), illetve Jager (2018) előzetes kutatásait is igazolta, amelyek szerint a terrorcselekmények elkövetőinek túlnyomó része iskolázott, középosztálybeli fiatal. E megállapítás pedig összhangban áll a racionális választás elméletével, mivel az azt feltételezi, hogy a marginalizált régiókból származó, alacsony iskolai végzettséggel rendelkező személyek mindennapjait a megélhetés biztosításáért folyó küzdelem tölti ki, így a meglévő normák megváltoztatására irányuló törekvések esetükben háttérbe szorulnak.

A tanulmány bebizonyította, hogy az erőszakos radikalizáció jelen sége komplex folyamat, így nem elegendő kizárólag a gazdasági as pektusokra szorítkozni, számos egyéb, azt erősítő folyamatot (ld. pél dául kulturális tényezők) szükséges vizsgálni. Tekintettel arra, hogy a járulékos tényezők részletes elemzése a jelen tanulmány keretét meghaladja, azok csupán említés szintjén szerepelnek. Az is kiderült, hogy az „arab tavaszt” követő belpolitikai és regionális instabilitás egyaránt közrejátszott a fiatal tunéziaiak extrém ideológiákkal történő szimpatizálásában, amely végüil az országot 2015-ben és 2016-ban megrázó terrorhullámhoz vezetett.

Jól látható, hogy a következő lépések elengedhetetlenek ahhoz, hogy Tunézia sikereket érjen el az erószakos radikalizáció elleni küzdelemben, és visszaszorítsa a demokratikus államberendezkedés megvalósulását aláásó jövőbeni terrorcselekményeket: ehhez a legfontosabb tényezô a fenntartható gazdaság alapjainak a megteremtése. A korábban marginalizált régiók fejlesztése pedig a fiatal generáció számára is stabil jövőképet teremtene. 


\section{Külïgyi Szemle}

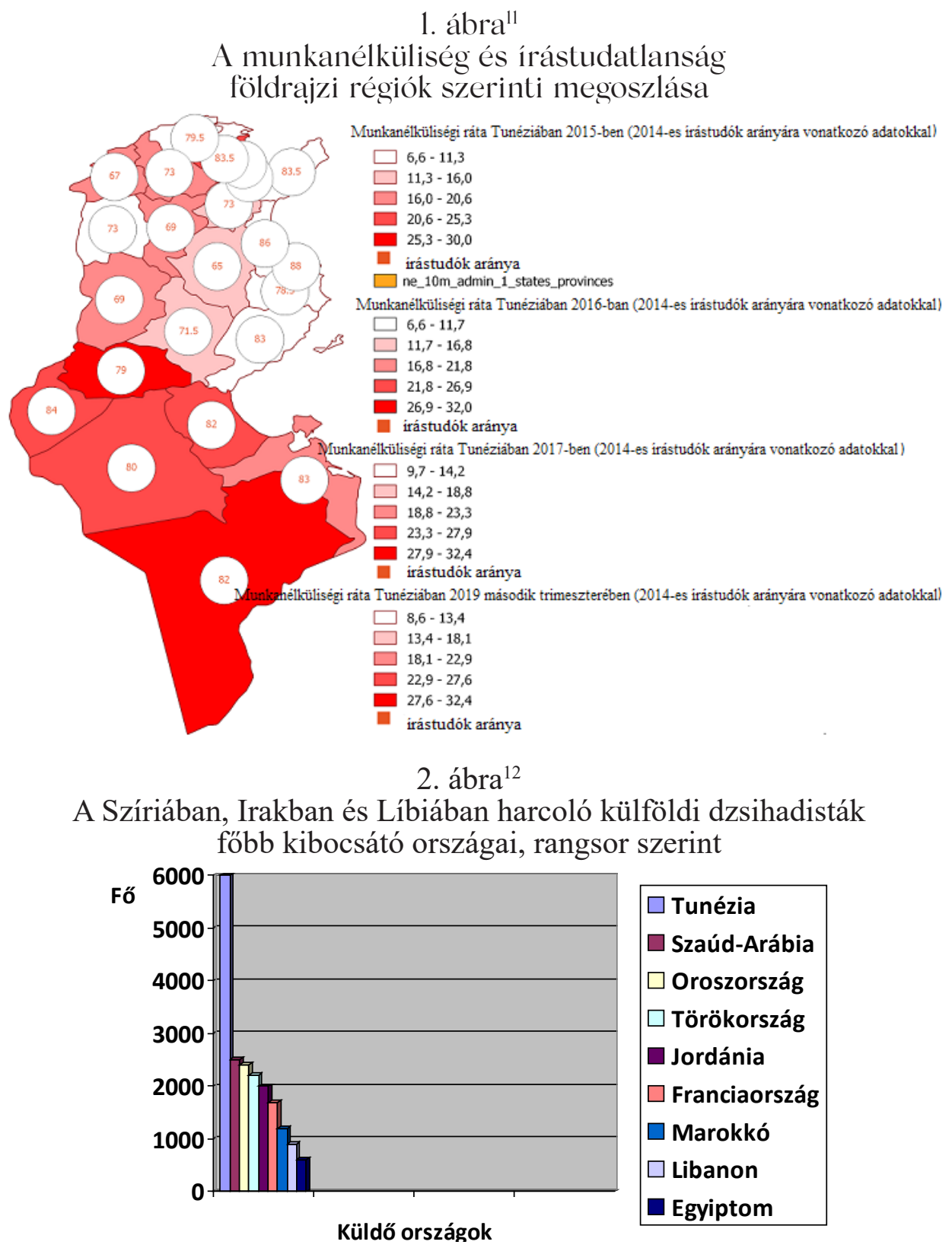

11 Forrás: Statistiques Tunisie, 2021.

12 Forrás: The Soufan Group, 2015. 


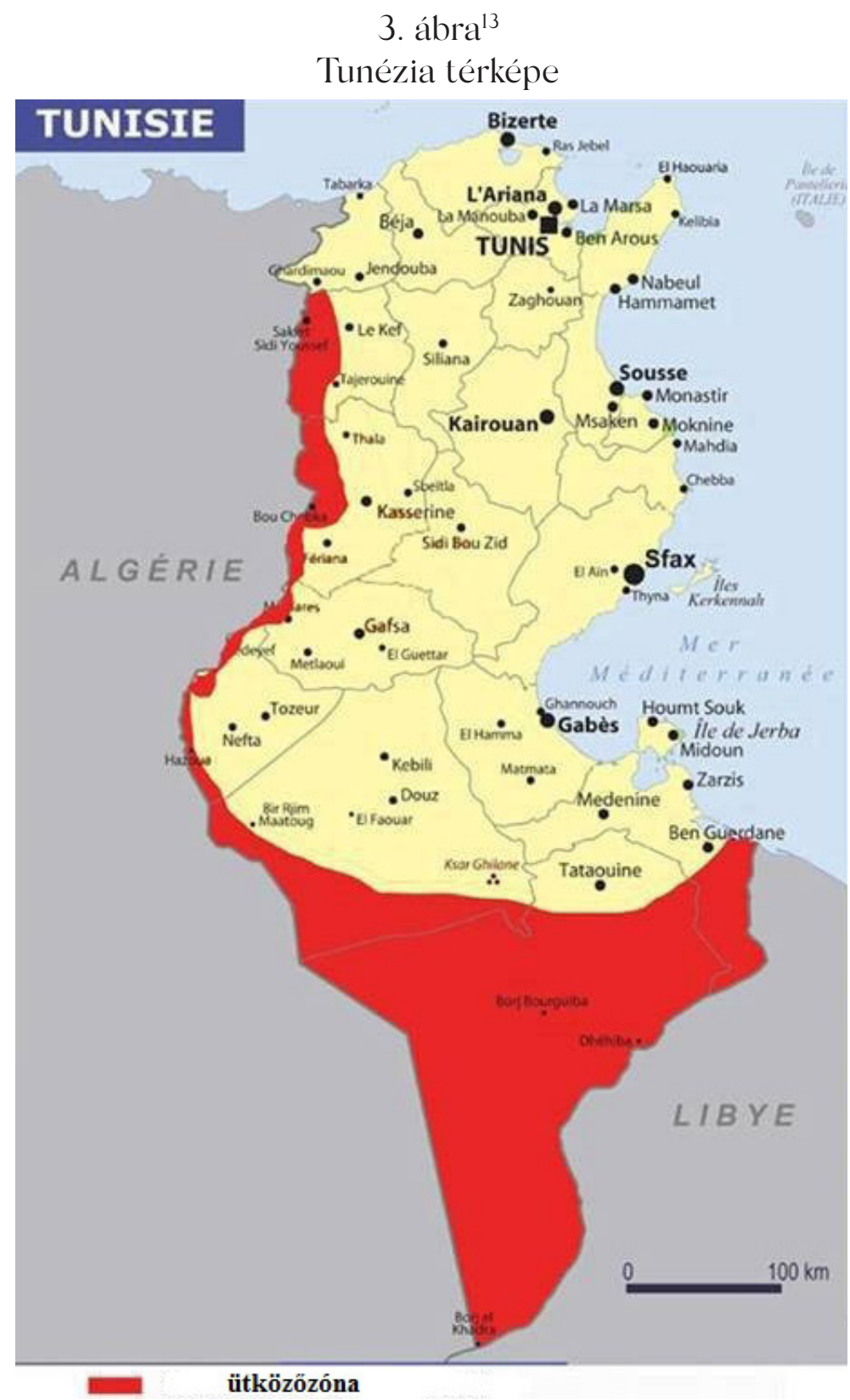

13 Forrás: Webmanagercenter, 2019. 


\section{Külïgyi Szemle}

\section{I rodalomjegyzék}

Alby, Stéphane (2015). Tunisie. Sévèrement touchée. BNP PARIBAS. A letöltés ideje: 2020. október 5. http://economic-research.bnpparibas. $\mathrm{com} /$ Views/WhosWho.aspx?Page=Page2\&uid=324127.

Alexander, Christopher (2010). Stability and Reform in the Modern Maghreb. London: Routledge.

Allani, Alaya (2007). Les Islamistes en Tunisie entre l'affrontement et la participation. In Muhammad Ayyadi, Hassan Rachik és Mohamed Tozy (szerk.), LIslam au qulodien. Enquêle sur les valeurs el les pratiques religieuses au Maroc.

Arany Anett, N. Rózsa Erzsébet és Szalai Máté (2016). Az Iszlám Állam kalifálusa. Az álalakuló Közel-Kelet. Budapest: Osiris Publishing.

Aubin, Yves de La Messuzière (2011). Mes années Ben Ali. Un ambassadeur de France en Tunisie. Tunis: Ceres Editions.

Barrett, Richard (2017). Beyond the Caliphate: Foreign Fighters and the Threat of Returnees. The Soufan Center.Aletöltés ideje:2020. szeptember 30. https://thesoufancenter.org/wp-content/uploads/2017/11/Bevondthe-Caliphate-Foreign-Fighters-and-the-Threat-of-Returnees-TSCReport-October-2017-v3.pdf.

Ben Yahmed, Marwane (2012). Les trois Tunisie. Jeune Afrique. A letöltés ideje: 2021. március 15. https://www.jeuneafrique.com/142287/politique/ les-trois-tunisie/.

Besenyő János és Prantner Zoltán (2015). The Emergence and Activity of Tunisia's Most Fearful Terrorist Group. Strategic Impact, 1, 137-150.

Black, Ian (2014). The Islamic State: Is it Isis, Isil - or Possibly Daesh? The Guardian. A letöltés ideje: 2021. máricius 14. https://www.theguardian. com/world/shortcuts/2014/sep/21/islamic-state-isis-isil-daesh.

Bobin, Frédéric (2016). Un an après l'attentat du Bardo, la Tunisie est plus que jamais confrontée au risque djihadiste. Le Monde. A letöltés ideje: 2020. október 3. http://www.lemonde.fr/international/article/2016/03/18/unan-apres-1-attentat-du- bardo-la-tunisie-est-plus-que-jamaisconfrontee-au-risque-djihadiste_4885599 3210.html.

Boer, Inge E., Moors, Annelies és Teeffelen, Toine van (1995). Changing Stories. Postmodernism and the Arab-Islamic World. Amsterdam: Rodopi. 
Business News (2015). Tunis - Attaque terroriste contre un bus de la Garde présidentielle. A letöltés ideje: 2020. október 1. http://www. businessnews.com.tn/tunis-attaque-terroriste-contre-un-bus-de-lagarde-presidentielle.520.60530.3.

Central Intelligence Agency. The World Factbook (2021). People and Society. A letöltés ideje: 2021. május 26. https://www.cia.gov/the-world-factbook/ countries/tunisia/\#people-and-society.

Colombo, Valentina (2016). Multiple Layers of Marginalization as a Paradigm of Tunisian Hotbeds of Jihadism. In Varvelli, Arturo (szerk.), Jihadist Hotbeds. Understanding Local Radicalization Processes (107-120. o.)

Crenshaw, Martha (1981). The Causes of Terrorism. Comparative Politics, 13(4), 379-399.

Csizmadia Sándor (2014). Tunézia: „Iszlamista” és „laikus” politikai erők alkotmányozási konszenzusa. Az arab világ legdemokratikusabb alkotmánya. Afrika Tanulmányok, 8(2), 7-41.

Daguzan, Jean-Francois (2017). Pourquoi la Tunisie produit-elle autant de jihadistes? Euromesco Policy Brief, 68. A letöltés ideje: 2020. szeptember 20. https://www.frstrategie.org/web/documents/ publications/autres/2017/2017-daguzan-epb-tunisie-djihadistes.pdf.

Dialmy, Abdessamad (2019). Un jihad sexuel genré. Mondopoli.it. A letöltés ideje: 2021. március 14. http:/www.mondopoli.it/wp-content/ uploads/2019/03/Un-jihad-sexuel-genr\%C3\%A9.pdf.

Duthion, Brice és Mandou, Cyrille (2016). Linnovation dans le tourisme. Culture numérique el nouveaux modes de vie. Louvain-la-Neuve: De Boeck Supérieur.

Dzhekova, Rositsa, Mancheva, Mila, Anagnostou, Dia és Stoynova, Nadya (2016). Understanding Radicalisation. Review of Literature. Center for the Study of Democracy. A letöltés ideje: 2020. október 6. https:// www.researchgate.net/publication/309732865_Understanding Radicalisation_Review_of Literature.

Euronews (2020). Attaque de Sousse: le president tunisien demande que la lumière soit faite sur les assaillants. A letöltés ideje: 2020. november 28. https://fr.euronews.com/2020/09/07/attaque-de-sousse-le-presidenttunisien-demande-que-la-lumiere-soit-faite-sur-les-assailla.

Fahmi, Georges és Meddeb, Hamza (2015). Market for Jihad. Radicalisation in Tunisia. Carnegie Middle East Center. A letöltés ideje: 2020. október 20. http://carnegieendowment.org/files/CMEC 55_FahmiMeddeb Tunisia_final oct.pdf. 


\section{Külïgyi Szemle}

France 24 in Arabic (2015). Men huva Szajf ad-Dín ar-Rezgí al mustabah bihi fi tanfiz i'tidá' Szúsza fí Túnisz. A letöltés ideje: 2020. október 1. http://www.france24.com/ar/20150627\% $8 \%$ AA $\%$ D9\%88\%D9\%86\%D8\%B3-\%D8\%A7\%D8\%B9\%D8\%AA\%D8 $\% \mathrm{AF} \% \mathrm{D} 8 \% \mathrm{~A} 7 \% \mathrm{D} 8 \% \mathrm{Al}-\% \mathrm{D} 8 \% \mathrm{~A} 5 \% \mathrm{D} 8 \% \mathrm{Bl} \% \mathrm{D} 9 \% 87 \% \mathrm{D} 8 \% \mathrm{~A} 7 \% \mathrm{D} 8 \% \mathrm{~A} 8-$ \begin{tabular}{lllllllllllllllllllllllll}
$\%$ & $\mathrm{D}$ & 9 & $\%$ & 8 & 1 & $\%$ & $\mathrm{D}$ & 9 & $\%$ & 8 & 6 & $\%$ & $\mathrm{D}$ & 8 & $\%$ & $\mathrm{~A}$ & $\mathrm{~F}$ & $\%$ & $\mathrm{D}$ & 9 & $\%$ & 8 & 2 \\
\hline
\end{tabular} $\begin{array}{lllllllllllllllllllllllll}\% & \mathrm{D} & 8 & \% & \mathrm{~B} & 3 & \% & \mathrm{D} & 9 & \% & 8 & \mathrm{~A} & \% & \mathrm{D} & 8 & \% & \mathrm{~A} & 7 & \% & \mathrm{D} & 8 & \% & \mathrm{~A} & \mathrm{D}\end{array}$ $\% \mathrm{D} 8 \% \mathrm{~B} 4 \% \mathrm{D} 8 \% \mathrm{~A} 7 \% \mathrm{D} 8 \% \mathrm{~B} 7 \% \mathrm{D} 8 \% \mathrm{~A} 6-\% \mathrm{D} 8 \% \mathrm{~B} 3 \% \mathrm{D} 9 \% 8 \mathrm{~A} \% \mathrm{D} 9 \% 81-$ \% $8 \%$ A7\%D9\%84\%D8\%AF $\%$ D9\%8A\%D9\%86-\%D8\%A7\%D9\%84\%D8\%B1 $\% \mathrm{D} 8 \% \mathrm{B2} \% \mathrm{D} 9 \% 82 \% \mathrm{D} 9 \% 8 \mathrm{~A}$.

Goaied, Mohamed (2019). Tourism, Terrorism and Political Violence in Tunisia: Evidence from Markov-Switching Models. Tourism Management, 70, 404-418.

Human Righls Walch (2017). World Report 2017. A letöltés ideje: 2020. október 1. https:/www.hrw.org/sites/default/files/world_report download/wr2017-web.pdf.

Jager, Avraham (2018). Does Poverty Cause Terrorism? International Institute for Counter-Terrorism. A letöltés ideje: 2020. október 23. https://www. ict.org.il/images/Does\%20Poverty\%20Cause\%20Terrorism.pdf.

Kiss Álmos Péter (2015). Afrikai terrorista-és szakadárszervezelek. Budapest: Honvéd Vezérkar Tudományos Kutatóhely.

Krueger, Alan B. és Maleckova, Jitka (2002). Education, Poverty, Political Violence and Terrorism: Is There a Casual Connection? National Bureau of Economic Research. A letöltés ideje: 2020. október 20. https://www. nber.org/papers/w9074.pdf.

LExpress (2019). Tunis: Daech revendique le double attentat qui a fait un mort et huit blessés. A letöltés ideje: 2020. október 29. https://www. lexpress.fr/actualite/monde/afrique/tunis-attentat-contre-la-policesur-la-principale-avenue-de-la-ville 2086560.html.

Law, Randall D. (2015). The Routledge History of Terrorism. Oxford: Routledge. Le Figaro (2018). Tunisie: Une femme s'est fait exploser dans le centre de Tunis, vingt blessés. A letöltés ideje: 2020. október 29. http://www. lefigaro.fr/international/2018/10/29/01003-20181029ARTFIGO0199tunisie-une-femme-s-est-fait-exploser-dans-le-centre-de-tunis-neufblesses.php.

Le Monde (2013). Tunisie : liens confirmés entre les meurtres de Mohamed Brahmi et Chokri Belaïd. A letöltés ideje: 2021. március 
14. https://www.lemonde.fr/tunisie/article/2013/07/26/tunisiemohamed-brahmi-tue-par-la-meme-arme-qu-un-autre-opposantpolitique $3454225 \quad 1466522 . h \mathrm{tml}$.

Le Monde (2013). Tunisie: Liens confirmés entre les meurtres de Mohamed Brahmi et Chokri Belaïd. A letöltés ideje: 2021. március 14. https://www.lemonde.fr/tunisie/article/2013/07/26/tunisiemohamed-brahmi-tue-par-la-meme-arme-qu-un-autre-opposantpolitique 3454225 1466522.html.

Le Programme du Mouvement Ennahda (2011). Pour une Tunisie de la Liberté, de la Justice et du Développement. A letöltés ideje: 2021. július 9. http://www.businessnews.com.tn/pdf/programme-ennahdha0911.pdf. Li, Quan és Schaub, Drew (2004). Economic Globalization and Transnational Terrorism: A Pooled Time-Series Analysis. The Journal of Conflict Resolution, 48(2), 230-258.

Lia, Brynjar (2005). Globalisation and the Future of Terrorism: Palterns and Predictions. London: Routledge.

Lounnas, Djallil (2019). The Tunisian Jihad: Between al-Qaeda and ISIS. Middle East Policy, 26(1), 97-116.

Lussato, Céline (2011). Tunisie. D'où vient le parti islamique Ennahda? LOBS. A letöltés ideje: 2021. március 14. https://www.nouvelobs.com/ monde/20111027.OBS3399/tunisie-d-ou-vient-le-parti-islamiqueennahda.html.

Mabrouk, Mehdi (2012). Tunisia: The Radicalistaion of Religious Policy. In George Joffe (szerk.), Islamist Radicalisalion in North Africa. Politics and Process (48-70. о.)

Macdonald, Geoffrey és Waggoner, Luke (2018). Dashed Hope and Extremism in Tunisia. Journal of Democracy, International Republican Inslitule. A letöltés ideje: 2020. november 28. https:/www.iri. org/resource/iri-experts-look-drivers-terrorism-tunisia-journaldemocracy.

Macmillan, Palgrave (2016). The Statesman's Yearbook 2017. The Politics, Cultures and Economies of the World. London: Springer.

Mejri, Walid (2017). „Terroristes” en Tunisie: que révèlent les dossiers judiciaires? Inkyfada. A letöltés ideje: 2020. november 28. https:// inkyfada.com/ $\mathrm{f} / 2017 / 01 / 04 /$ terroristes-tunisie-dossiers-justice/.

Moghadam, Valentine M. (2016). Islamism, Feminism and Resistance: Rethinking the Arab Spring. In David Courpasson és Steven Vallas (szerk.), The SAGE Handbook of Resistance (78-95. o.) 


\section{Külïgyi Szemle}

Ogu, Michael I. (2013). Rational Choice Theory: Assumptions, Strengths, and Greatest Weakness in Application Outside the Western Milieu Context. Arabian Journal of Business and Management Review, I(3), 90-99. A letöltés ideje. 2020. október 8. https://pdfs.semanticscholar. org/88f8/5e5laad54ef5a 564 e270bf54 ce5ba8fdf 3 da.pdf? $\mathrm{ga}=2.58601898 .1276011796 .1567944859-33309935.1565636219$.

Reuters (2020). Nice Attack Points to Continued Tunisian Struggle with Jihadists. A letöltés ideje: 2020. november 28. https://www.reuters. com/article/france-security-nice-tunisia-idUSKBN27F097.

Rivlin, Paul (2014). Tunisia: What Ben Ali Stole. Middle Easl Economy. 4(5), $1-6$.

Sánchez-Cuenca, Ignacio (2019). The Historical Rools of Political Violence: Revolutionary Terrorism in Affluent Countries. Cambridge: Cambridge University Press.

Statistiques Tunisie (2021). Indicateurs clés. A letöltés ideje. 2021. május 29. http://www.ins.tn/.

Taspinar, Ömer (2009). Fighting Radicalism, not 'Terrorism': Root Causes of an International Actor Redefined. SAIS Review, 29(2), 75-86. o. A letöltés ideje: 2020. október 5. https://www.brookings.edu/wpcontent/uploads/2016/06/summer fall radicalism taspinar.pdf.

The Soufan Group (2015). Foreign Fighters. An Updated Assessment of the Flow of Foreign Fighters into Syria and Iraq. A letöltés ideje: 2020. december 6. https://www.jstor.org/stable/resrepl0784.

Tolan, Patrick H. (2007). Understanding Violence. In Daniel J. Flannery, Alexander T. Vazsonyi és Irwin, D. Waldman (szerk.), The Cambridge Handbook of Violent Behavior and Aggression (5-18. o.)

TRAC (é. n.). Search Results. A letöltés ideje: 2020. november 30. https:// www.trackingterrorism.org/search/apachesolr_search/Tunisia.

UNdata (2021). Tunisia. A letöltés ideje: 202. május 29. http://data.un.org/en/ iso/tn.html.

Webmanagercenter (2019). Le ministère de la Défense nationale appelle à éviter les zones militaires fermées et des zones tampon. A le töltés ideje: 2020. december 6. https://www.webmanagercenter. com $/ 2019 / 08 / 26 / 438134 /$ le-ministere-de-la-defense-nationaleappelle-a-eviter-les-zones-militaires-fermees-et-des-zones-tampon/.

Winston, David (2018). DIY Terrorism: A Look At The Paradigm Shift in Daesh's Recruitment Tactics Through The Lense of Central Asian 
Foreign Terrorist Fighters. Hungarian Defence Review, 146(1), 4-16. A letöltés ideje: 2020. november 15. https:/kiadvanv.magvarhonvedseg. hu/index.php/honvszemle/article/view/301.

Wolf, Anne (2014). The Radicalisation of Tunisia's Mosques. CTC Sentinel, 7(6), 17-19. o. A letöltés ideje: 2020. november 8. https://ctc.usma.edu/ the-radicalization-of-tunisias-mosques.

World Bank (2014). Tunisia. Breaking the Barriers to Youth Inclusion. Youth Inactivity and Unemployment. A letöltés ideje: 2020. november 21. https://www.worldbank.org/content/dam/Worldbank/document/MNA/ tunisia/breaking the barriers to youth inclusion eng chap3.pdf.

Yahmed, Marwane Ben (2012). Les Trois Tunisie. Jeune Afrique. A letöltés ideje: 2021. május 25. https://www.jeuneafrique.com/142287/politique/ les-trois-tunisie/.

Zaarour, Khodr M. (2016). State-Sponsored Terrorism and Its Effects on Lebanese Policy and Politics. In Alexander R. Dawoody (szerk.), Eradicating Terrorism from the Middle East. Policy and Administrative Approaches. Cham (185-199. o.) 